\title{
IMPROVING STUDENTS'ACHIEVEMENT IN READING COMPREHENSION THROUGH TEAM PAIR SOLO
}

\author{
IQBAL FAISAL RAMBE \\ Dra. Masitowarni Siregar,M.Ed. \\ English Department, Faculty of Languages and Arts \\ State University of Medan \\ Medan - Indonesia
}

\begin{abstract}
This study attempts to improve students' achievement in reading comprehension through team pair solo. This study was conducted by using classroom action research. The subject of this research was class VIII ${ }^{2}$ MTs Al-jihad which consisted of 41 students. The research was conducted in two cycles, cycle I consisted of four meetings and cycle II consisted of two meetings. The instruments for collecting data were quantitative data (reading comprehension test) and qualitative data (diary notes, observation sheet, and questionnaire sheet). Based on reading comprehension scores, students' score kept improving in every reading comprehension test. Based on diary notes, observation sheet, and questionnaire sheet, it was found that the teachinglearning process ran well. The students were active, interested, and enthusiastic in reading. The result of the research showed that team pair solo significantly improved students' achievement in reading comprehension.
\end{abstract}

Key Words: reading, reading comprehension, team pair solo

\section{INTRODUCTION}

\section{Background of Study}

English becomes the most essential language in the world. Almost all the people from many different countries around the world use it to comunicate. The area of English has always become a special interest. It is because of the importance of English in any scope of our lives. Dealing with the facts that English is a global language to create a competitive generation in all aspect of life. Indonesia education includes 
English subject in the curriculum of primay school up to senior high school. It means that English becomes an obligatory subject and students are supposed to learn English since the early ages. It is one effort to make students master English with its four skill; listening, speaking, reading and writing to creat a generation of innovation.

In studying English, there are four aspects that will be learned that are speaking, reading, listening and writing. The four elements are mutually supportive and have a relationship each other. The ability to read is one of the most important thing in learning English because by reading we will be able to improve science and will obtain the latest information that we obtain from the kit discourse punctuation, this statement is related to Ellen (2008) state that Reading is a very important part of our lives. We need to take time every day and read at least 20 to 30 minutes a day. It really helps when you read out aloud. You can hear yourself and see how you pronounce your words. Your reading will improve if you keep reading out aloud. You should take whatever steps needed to help you learn the art of reading (http://bookstove.com). When you read, you will open up a life time of learning. When you read, you will gain knowledge and understanding of what you have just read.

Based on the explanation above, the ability to read is very important for being mastered by students. Reading, according to Patel and Jain (2008:113) is an active process which consists of recognition and comprehension skill, an important skill activity in life with which one can update his/her knowledge, and important tool for academic success.

In fact, not all students are able to comprehend to reading text. Based on the researcher's observation at the time of the teaching practice program (PPL) many students do not comprehend to read text, although the English teacher had already teached material to students. In addition, the researcher also looked at the English teacher teaching by lecture, and then asked the students to read text individually although the students do not know what they have read.

From that observation, students' comprehension to read text was very low because the learning method that was adopted by the English teacher is a method which is not fit any more in this day because it will reduce the interest and liveliness of the students in the learning process so that students were bored and do not want to continue learning as they should. 
In this teaching reading, the teacher teaches students by asking them only to read text and answer the questions. These activities do not give any opportunities to improve students' knowledge. It also cannot give more contribution to students in understanding reading comprehension. In this case, most students still find difficulties to comprehend a reading text.

In fact, the process of teaching reading comprehension cannot run well because most students are not interested to learn reading comprehension in the class. They only read and answer the questions without raising some questions to get some information from reading text. As consequence, learning reading comprehension make them bored. The teacher must know the suitable strategy for students to make the students more comfortable in the class especially in learning reading skill.

Students' reading skill actually can be improved by using Team Pair Solo. Many methods can be used in order to help improving the students' comprehension but for this thesis the method used is Team Pair Solo. Team Pair Solo is one of the methods which can be applied in teaching reading. It is good methods which can make students interact actively in the class activity, especially in reading lesson because it can stimulate students to think and change their thinking.

Team Pair Solo (TPS) is a method of cooperative learning in which the students do problem first as a team, then with a partner, and finally on their own (Jane, 2007:8). It is designed to motivate the students to tackle and succeed at problem which initially were beyond their ability. And then all students take individual quizzes on the material, at that time they must not help each other. It was based on the simple nation of mediated learning. Obviously, one alternative to solve the problem of reading text is by applying TPS.

Based on the students' condition in teaching learning process, it is hoped that using Team Pair Solo is good way of teaching reading comprehension to help the students to promote critical thinking about what they read by solving problem first in team, then in pair and finally in their own. This method is designed to motivate students to tackle and succeed at problems which initially are beyond their ability. In other word, by using Team Pair Solo in teaching reading comprehension, it can improve the students reading skill. 


\section{Research Question}

'Does Team Pair Solo method improve students' achievement in reading comprehension?"

\section{Conceptual Framework}

Many students assume that reading is just the act of saying words to their teacher or to themselves or to depending on whether they are reading only orally or silently. They have not learned that reading is an essence an exchange of ideas between an author and themselves (Smith and Johnson, 1980:4). In simple way Mackay (1979) says that reading is an active process.

Therefore, readers need three aspects: making prediction, thinking of the text that it is even of life and having similarity to the human life. In addition, Burns (1984:10) says that reading is a thinking process. It involves interpretation of implicit and explicit meaning of written texts, connecting interaction of ideas between reader and writer, analyzing and applying new information to the new situation.

Comprehension is a special kind of thinking process. Anderson and Pearson (1984:60) states that the reader comprehends by actively constructing meaning internally from interacting with the material that is read. In addition, Bernhardt et.al (2003:14) says that comprehension is an interactive process in the construction of meaning. Readers must use information already acquired to filter, interpret, organize, reflect upon and establish relationship with the new incoming information. In order to understand text, a reader must be able to identify words rapidly, know the meaning of all most of the words and be able to combine units of meaning into a coherent message.

In conclusion, reading comprehension is an interaction between thought and language to get the meaning of a text.

Level of comprehension refers to the degree in which a reader can be categorized as good as poor readers, proficiency or less proficiency readers. It means that how far the students understand the information gotten from the text and which level that has been achieved. Smith and Barrett (1988:246-247) divide comprehension into four levels of reading comprehension that must be achieved in reading comprehension. They are: 


\section{Literal comprehension}

Literal comprehension refers to the ability to understand what stated by the writer or taking the idea and facts that are directly stated on the printed page. The basic of literal comprehension is recognizing stated main idea, detailed, cause effect, and sequence. Mastering the basic of literal comprehension, can be done through understanding of vocabulary, sentence meaning, and paragraph meaning. The literal level is the easiest level of reading comprehension because a reader is not required to go beyond what they actually said.

In this level, the readers know the words meaning, able to paraphrase or recall of details directly in own words.

\section{Inferential Comprehension}

Inferential comprehension refers to the ability to go beyond what is stated directly, to understand what the writer means by looking for the inside meaning. Readers identify and derive ideas and meaning from a text they are explicitly stated. It can be said that inferential comprehension is the ability to get inference or implied meaning from the text.

In this level, the reader is able to infer factual information, main idea, comparisons, causes-effects relationship which is not explicitly stated in the passage.

\section{Critical Comprehension}

Critical comprehension refers to the ability to make analysis, evaluation, judgment and personal reacting about the ideas of information that writers offers in a passage. It requires a higher degree of skill development and perception. In critical reading, readers evaluate written material; compare the ideas found in the material with his/her previous knowledge and draw conclusion appropriately. In other words, the reader compares his previous experience to the element of the new material of the passage.

\section{Creative Comprehension}

Creative comprehension refers to the ability of reader to use his/her imagination when reading the passage. Skills for creative reading comprehension include the understanding cause-effect relationship on a story solving problem and producing the creations. 
In this level, the reader able to product a new idea, develop his new insight through the reading materials.

This study is concerned with the improvement of reading comprehension narrative text through the application of Team Pair Solo Method. It is concerned about the students ability in comprehend narrative text.

Team Pair Solo is one of the Cooperative Learning Methods that Students do the problems first as team, then with a partner, and finally on their own. It is designed to motivate students to tackle and succeed at problems which initially are beyond their ability. It is based on a simple notion of mediated learning. Students can do more things with help (mediation) than they can do alone. By allowing them to work on problems they could not do alone, first as a team and then with a partner, they progress to a point they can do alone that which at first they could do only with help.

Here are the step-by-step procedures of Team Pair Solo Kagan (1998:23):

1. Team: engage in reading activities or recognize the use of literary devices

2. Pair: interpret, make inferences or draw conclusions

3. Solo: construct a personal response to texts

\section{METHODOLGY}

\section{Research Design}

This study was conducted as classroom action research. Action research is defined as any systematic inquiry conducted by teacher, administrators, counselors or other with vested interest in the teaching learning process or environment for the purpose of gathering information about how their particular schools operate, how the teach and how their students learn. Stringer (2007:1) maintains that action research is systematic approach to investigation that enables people to find effective solutions to problems they confront in their everyday life. Action research focuses on specific situations and localized solutions. Action research provides the means by which people in schools, business and community organizations; teachers; and health and human services may increase the effectiveness of the work in which they are engaged.

\section{The Subject of the Research}

The subject of this research was students in class VIII of MTS Al-Jihad J1. Asahan Kerasaan Kec. Pematang Bandar Kabupaten Simalungun. 


\section{The Instrument of Collecting Data}

In collecting the data, the following instruments used are

1. Reading comprehension essay test.

2. Observation sheet. Observation sheet has function to identify all the condition that happened during the teaching and learning process.

3. Diary notes. Diary notes are personal records usually done by researcher itself that will be written up daily.

4. Questionnaire sheet. Questionnaire sheet is used to know whether the students felt enthusiastic and have interest in learning reading comprehension using group competition strategy.

\section{The Procedure of Research}

This research was conducted into two cycles; where in each cycle applied four steps: (1) planning, (2) action, (3) observation, and (4) reflecting. In conducting this research, the steps are as followed:

\section{Cycle I}

\section{Planning}

The researcher made an observation to know students' problem in reading comprehension before doing the research. Based on the result, it was found that the students' reading comprehension skill was still low. To solve that problem, Team Pair Solo would be applied. The researcher made lesson plan which involved the scenario of teaching. In this research, the researcher would be as the teacher and the English teacher would be the collaborator who observed the teaching learning process in which the use of Team Pair Solo was implemented.

\section{Action}

In this session, there were four meetings. There were many things done by researcher. It was started by explaining the definition and the level of reading comprehension. After that, students were given essay test of reading comprehension. Then, in the second meeting, Team Pair Solo was introduced to the students. The researcher explained the procedure of Team Pair Solo. After that, the students were divided into a small group to apply Team Pair Solo in doing essay test of reading comprehension. 


\section{Observation}

In this session, the researcher observed and wrote students' activity during teaching and learning process. The researcher used observation sheet and diary notes to get the result. Some of students did not seriously to follow the study because the teacher explained too fast. Some of them were inactive and the other disturbing their friends by making any noisy because they did not like reading.

\section{Reflection}

In this session researcher did an evaluation from the action which has been done before. It is used to help teacher makes decision by analyze the situation and the students' difficulties or problem in understanding the lesson. In this phase, researcher took the feedback from the teaching and learning process from the result of the observation and the students' test. The purpose is to improve students' achievement in reading comprehension. From the data was found that in the first cycle there were only $60.97 \%$ students who got point up 65 . So for that case, cycle 2 was conducted to get better result.

\section{Cycle II}

\section{Planning}

Based on the result of the first cycle, the writer decided to continue to the second cycle. The first cycle indicated that the students' scores were still low. It happened because the students still got difficulties and the interaction between the teacher and the students was not effective enough. At this time, the students would be taught by more interesting strategy than taught in the cycle I.

\section{Action}

In this session, before giving essay test, the teacher explained more detail about reading comprehension. Then, they were taught how to arrange and answer w-h and yes-no questions and they were asked to discuss the text. After that, they were given essay test.

\section{Observation}

In this session, the teacher observed the process of studying and learning using observation sheet, diary notes, and questionnaire. The result showed that the students became more active and serious during the lesson. The situation of the class during teaching learning process was livelier than in the first cycle. Not only they responded 
every question asked by the teacher well, but also they were not shy to ask some questions about unclear points anymore.

\section{Reflection}

Based on the reading test scores and the observation result in cycle 2, students' reading scores were improved. It was found that most of the students got satisfying achievement. From the observation results in every meeting, it could be concluded that the teaching-learning process in which Team Pair Solo was applied had ran well. The situation during teaching-learning process was conducive, lively, and active. The interaction between teacher and students was better than that of in the first cycle. The cycle of this research could be stopped because the students' achievement in reading comprehension had been improved significantly.

\section{RESULT AND DISCUSSION}

Both quantitative and qualitative data were organized from the whole meetings. The first cycle was begun by giving test $\mathrm{I}$ in order to discover the ability of the students in reading text before the use of team pair solo. From the result of the test I, it was found that students' achievement in reading comprehension was still low. They were still confused in comprehending the text. Then, they were taught by using Team Pair Solo. After conducting test II in cycle 1, students' reading scores was better than test I, but the percentage of students who achieved the standard score was not $70 \%$ yet. They still got some difficulties. After that, the cycle 2 was conducted and they were given more explanation about how to comprehend the text by using Team Pair Solo in detail. The result of test III showed that students' reading scores significantly improved. Most students had already achieved the standard score.

Based on qualitative data gathered from observation sheet, questionnaire sheet and diary note during cycle 1 and 2, it was found that students also made improvement while teaching-learning process. Observation and diary notes result showed that the students were more active during the teaching learning process. In the beginning, not all the students were interested in studying. There were found some students chatted during the lesson. Besides that, they were still shy when they were given chances to ask questions about unclear points. But in the next meetings, the students showed their enthusiasm either in asking or answering questions. The questionnaire showed that 
students strongly agreed that the use of team pair solo had helped them in comprehending the text. These all qualitative data supported the research findings which were based on the quantitative data. Based on the results of quantitative and qualitative data, it was found that the use of team pair solo had been successfully improved students' achievement in reading comprehension.

\section{CONCLUSION AND SUGGESTIONS}

\section{Conclusion}

After analyzing the data, it was found that the use of team pair solo could help students in comprehending text. It also made teaching-learning process enjoyable and decreased students' boredom in studying English. As the result, students' score in reading comprehension increased. Thus, the use of team pair solo in teaching significantly improved students' achievement in reading comprehension.

\section{Suggestions}

The result of this study showed that the use of team pair solo could improve students' reading comprehension. Therefore the suggestions are as follows:

a. The English teacher are suggested to use Team Pair Solo as teaching strategy to stimulate the students' learning reading spirit in the teaching reading process.

b. The students should make questions related to a text and use Team Pair Solo to comprehend the text, because it can stimulate the students' critical thinking in reading comprehension.

Other researcher could improve the research dealing with the use of Team Pair Solo on reading comprehension. 


\section{REFERENCES}

Patel, M \& Jain, P. 2008. English Language Teaching. Jaipur. Sunrise Publishers \& Distributors.

Brown, H. D.2001. Teaching by Principles, An Interactive Approach to Pedagogy. New York: Longman.

Burns, et al. 1984. Teaching in Today's Elementry School (Third Ed). New York: Longman.

Bernhardt, et.al. 2003. Teaching reading. Available in http://www.ibe.unesco.org. Accessed on January 15, 2012.

Kagan. 1998. Smart Card of Cooperative Learning Structures. Virginia: Language Education Consultant.

Smith, Louis M., and Hudgins, Bryce B. 1964. Educational Psychology. An Application of Social and Behavioural Theory. New York. Alfred. A. Knopt.

Stringer, ernest t. 2007. Action Research Third Edition. United State of America: Sage Publication Inc.

(http://bookstove.com)

(http://www.merriam-webster.com/dictionary/ method)

(http://edtech.kennesaw.edu/intech/cooperativelearning.htm) 